\title{
Description of Avian Bio-Diversity of Damdamma Jheel in Gurgaon District in Haryana, India
}

\author{
ROHTASH CHAND GUPTA ${ }^{1}$ AND TIRSHEM KUMAR KAUSHIK ${ }^{2 *}$
}

\author{
${ }^{1}$ Department of Zoology, Kurukshetra University Kurukshetra. \\ ${ }^{2}$ Salim Ali Centre for Ornithology and Natural History, Coimbatore.
}

\begin{abstract}
Damdamma Jheel is a wetland of impressive potentials of harboring rich avian bio-diversity in the accompaniment of enhanced habitat reconstruction and improvement. It is located in the National Capital Region, nearby Sohana town in Gurgaon district in Haryana merely $45 \mathrm{Kms}$ from Dhaula Kuan in New Delhi, India. The present studies focus attention on its avian biodiversity as well as its own degraded form and structure. In all, 128 species of birds belonging to 15 orders and 41 families could be enlisted. Order Passeriformes is the predominant one having 54 species, followed by Charadriiformes (14 Species) and Ciconiiformes (12 Species). The prominent winter migratory birds observed from Damdamma Jheel include Asian Openbill Stork Anastomus oscitans, Eurasian Spoonbill Platalea lencorodia, Northern Shoveller Anas clypeata, Northern Pintail Anas acuta, Common Teal Anas crecca, Common Pochard Aythya ferina, Gadwall Anas strepera, Spot-billed Duck Anas poecilorhyncha, Spotted Redshank Tringa erythropus, Common Redshank Tringa totanus, Common Greenshank Tringa nebularia, Kentish Plover Charadrius alexandrinus, White-tailed Lapwing Vanellus leucurus, Marsh Sandpiper Tringa stagnatilis, Wood Sandpiper Tringa glareola, Common Sandpiper Actitis bypoleucos, White Wagtail Motacilla alba and Yellow Wagtail Motacilla flava. The very fact that in October 2012, a large group of Open-bill Storks (Nearly 70-80) have already arrived at Damdamma Lake w.e.f. September2012 indicates that it is the largest harbour of Open-bill Stork in Haryana. Also, Eurasian Spoonbills were seen in groups of 10-12, again the largest in Haryana. It is argued in this paper, that Damdamma is the pride lake of Haryana in India and prime harbor for uncommon winter migratory birds like Open-bill Stork and Eurasian Spoonbill must be the prime place for habitat reconstruction by Ministry of Environment and Forest, Govt. of India in conjunction with Govt. of Haryana with the active contributions by WWF (India). It can be a nodal point to include Sultanpur National Park, Badkhal Lake, Bhindawas and Keoladeo National Park as an "eco-tourism rectangle" with provision for night halt for tourists of all hues nearby Indian National Capital of Delhi.
\end{abstract}

Keywords: Avian diversity, Damdamma Jheel, Gurgaon, Haryana

\section{INTRODUCTION}

Haryana state in India is devoid of natural lakes, whatsoever. It is a paradox that until 2005 or so, the only National Park of Haryana, namely Sultanpur National Park is infact, an artificial Lake. This artificial lake suffers from sustained water scarcity. Similarly, Badkhal Lake in Faridabad District, although impressively vast in expanse, is in doldrums since last 10-20 years. In these circumstances, Damdamma jheel in Gurgaon district nearby Sohna town is poten-

*Corresponding address:

Tirshem Kumar Kaushik

Ex. Scientist, Salim Ali Centre for Ornithology and Natural History, Coimbatore, India.

E-mail:tarshemkaushik@rediffmail.com tially a good lake. Just because it is in close proximity with Sultanpur National Park and not very far off from Keoladeo National Park of Bharatpur and Bhindawas jheel in Jhajjar, Damdamma jheel calls for better recognition by Wildlife Department of Govt. of Haryana. Similarly, it has also the possibility of attaining tourism-Contours being in close association of Suraj-Kund Tourist complex of Haryana in India. Damdamma Lake is located at a distance of $55 \mathrm{Kms}$ from "Cannaught Place" of Delhi. It is the biggest natural lakes in Haryana near Aravalli Hills. In 1991, Damdamma Saras resort was built by Haryana Tourism department. It is pertinent to mention that wetland birds in Haryana have been studied by Gupta and Kaushik [1-8]; Gupta et al. [9-11] and Gupta et al. 
(12-16]. No one has focused attention on avian biodiversity of Damdamma Jheel in India and hence the present studies.

\section{Study Site}

Damdamma Jheel is a very healthy wetland. It is located in district Gurgaon nearby Sohna town in Haryana near Aravalli Hills. Damdama Lake is known as nature's paradise and located in the lap of Aravali hills. Damdama Lake is just $23 \mathrm{~km}$ from Gurgaon and $42 \mathrm{~km}$ from Delhi. It is approximately $9 \mathrm{~km}$ from Sohna. It can be approached from Delhi by travelling to Gurgaon city to Sohana town and finally to Damdamma Jheel. Actually this Jheel is very near to village Damdamma and hence its name. Also, its very designation as Jheel verifies its potential deep and vast expanse compared to a traditional pond/Pokhar. Its exact geographical position is $28^{\circ} 18^{\prime} 14^{\prime \prime} \mathrm{N} 77^{\circ} 07^{\prime} 44^{\prime \prime} \mathrm{E} 28.304^{\circ} \mathrm{N} 77.129^{\circ} \mathrm{E}$. Its general appearance is substantiated by Fig.3. It is an artificial Jheel built in 1947 by the Britishers to harvest rainy water in a hilly terrain of the receding Aravalli Hills in Gurgaon district in Haryana. It is perhaps the biggest water body in Haryana. It is one of the most unkept, uncared for and neglected nature- related tourists spot in the very bosom of our national capital where facilities for varied water sports are available. It is 20-60 feet deep having blue waters in the very serene pristine, divine and exclusive environs. It is a prime place for variety of winter migratory birds and few of them available only in this lake and nowhere else in Haryana. The present studies aim to highlight the magnanimity of this vast wetland and its uniqueness to receive migratory birds in terms of very rare and globally sensitive birds. The present studies attempt to requisite substantial care from quarters assigned the duty to protect and conserve wetlands as also their winter migratory birds which come to India.

\section{MATERIALS AND METHODS}

The present studies have been carried out during 2005 to 2012 for the investigation of avian diversity of Damdamma Jheel in Gurgaon district in Haryana, India. Several visits have been made w.e.f. 2005. However the present paper is based on express visits made in October 2012 to dwell on the pitiable condition and its incapability to serve as a habitat to provide bare minimum needs to Open-bill Stork and Eurasian Spoonbill and many more other resident as well as wetland birds. Extensive photography has been done with the help of Zenith Camera with Russian made tele-lens and Digital Nikon Coolpix P500 camera. The entire precincts of the wetland were analyzed in depth and evidence. Just because Damdamma Jheel is a beautiful wetland, many people visit it for recreation. Birds were identified with the help of field guides and reference books [17-20, 21]. The nomenclature follows Manakadan and Pittie [22]. The aim is to understand the avian potential of this grand lake of Haryana.

\section{RESULTS AND DISCUSSION}

The avian biodiversity is contained in Table-1. It is evident that a total of 128 species of birds can be spotted at Damdamma Jheel. In all15 orders are represented.

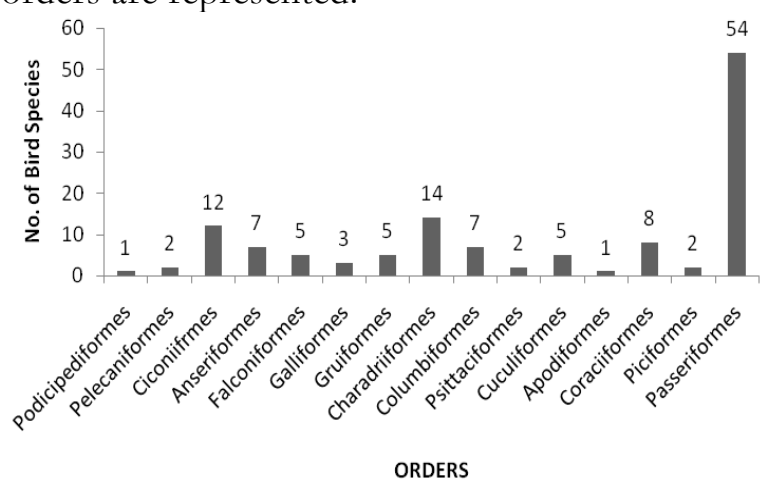

Fig.1. Showing incidence of avian biodiversity spotted in Damdamma Jheel in Gurgaon district in Order-wise manner during 2005-2012

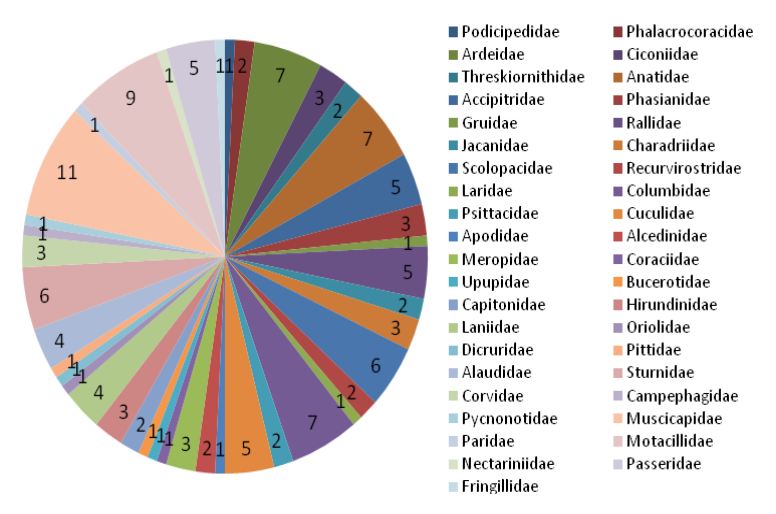

Fig.2. Showing incidence of avian biodiversity spotted in Damdamma Jheel in Gurgaon district in familywise manner during 2005-2012

The highest numbers of species of birds are contained in Order Passeriformes (54 Species) spread over 16 families including Hirundinidae, Laniidae, Oriolidae, Dicruridae, Pittidae, Alaudidae, Sturnidae, Corvidae, Campephagidae, Pycnonotidae, Muscicapidae, Paridae, 
Motacillidae, Nectariniidae, Passeridae and Fringillidae. Similarly, the lowest species of birds is found in order Podicipediformes and Apodiformes. Gupta et al. [13] reported 192 species of birds from Bhindawas Bird Sanctuary in Jhajjar district in Haryana. At the same time Gupta et al. [16] reported 164 species of birds belonging to 16 Orders, 44 families from Khaparwas Bird Sanctuary in Jhajjar district. It is interesting to point out that birds like Darter Anbinga melanogaster, Chestnut Bittern Ixobrychus cinnamomeus, Glossy Ibis Plegadis falcinellus, Greater Flamingo Phoenicopterus ruber, Graylag Goose Anser anser, Bar-headed Goose Anser indicus, Brahminy Shelduck Tadorna ferruginea, Mallard Anas platyrbynchos, Eurasian Wigeon Anas Penelope, Garganey Anas querquedula, Tufted Pochard Aythya fuligula, Pallas Fish Eagle Haliaeetus leucoryphus, Egyptian Vulture Neophron percnopterus, Eurasian Curlew Numenius arquata, Common Snipe Gallinago gallinago, Indian Courser Cursorias coromandelicus and Black bellied Tern Sterna acuticauda could not be observed from Damdamma jheel but reported from Bhindawas Bird Sanctuary in Jhajjar district in Haryana [17].

The peculiar large sized wetland birds include, amongst several others, Saras Crane Grus antigone, Asian Open-bill Stork, Painted Stork, Whitenecked Stork, Grey Heron, Eurasian Spoonbill, Great Egret and Purple Heron. The fanciful Jheel include Woodpeckers and Kingfishers. It is pertinent to mention that Saras Crane was spotted in agriculture field in the vicinity of Damdamma Jheel in 2007 only. After that Saras Crane was never seen. It is crucial to mention that a large flock of Asian Open-bill Storks (approximately 60-70) were spotted regularly from Damdamma Jheel during 2005-2012. At the same time, White-necked Stork, Oriental White Ibis and Painted Storks were observed rarely.

Regular winter migratory birds seen in winter include Asian Open-bill Stork Anastomus oscitans, Eurasian Spoonbill Platalea leucorodia, Northern Shoveller Anas clypeata, Northern Pintail Anas acuta, Common Teal Anas crecca, Common Pochard Aythya ferina, Gadwall Anas strepera, Spot-billed Duck Anas poecilorbyncha, Spotted Redshank Tringa erythropus, Common Redshank Tringa totanus, Common Greenshank Tringa nebularia, Kentish Plover Charadrius alexandrinus, White-tailed Lapwing Vanellus leucurus, Marsh Sandpiper Tringa stagnatilis, Wood Sandpiper Tringa glareola, Common Sandpiper Actitis bypoleucos, White Wagtail Motacilla alba and Yellow Wagtail Motacilla flava.

It is interesting to note that Red-crested Pochard, Tufted Pochard, Mallard, Garganey,
Pallas's Gull and Black-headed Gull sighted elsewhere in Northern Haryana [8-9] are seldom sighted in Damdamma Lake in winter season in southern Haryana. Little Egrets, Pond Herons, Egrets, Black winged Stilts, Red-wattled Lapwing (in plenty) are seen regularly. Our studies hints towards one salient feature of Damdamma Lake in respect of its avian peculiarity is that Asian Open-bill Stork and Eurasian Spoonbill migratory birds are seen in largest groups in Haryana territory; Open-bill Stork may reach a number nearby 80-100. Eurasian Spoonbill may reach a number nearby 20-30.
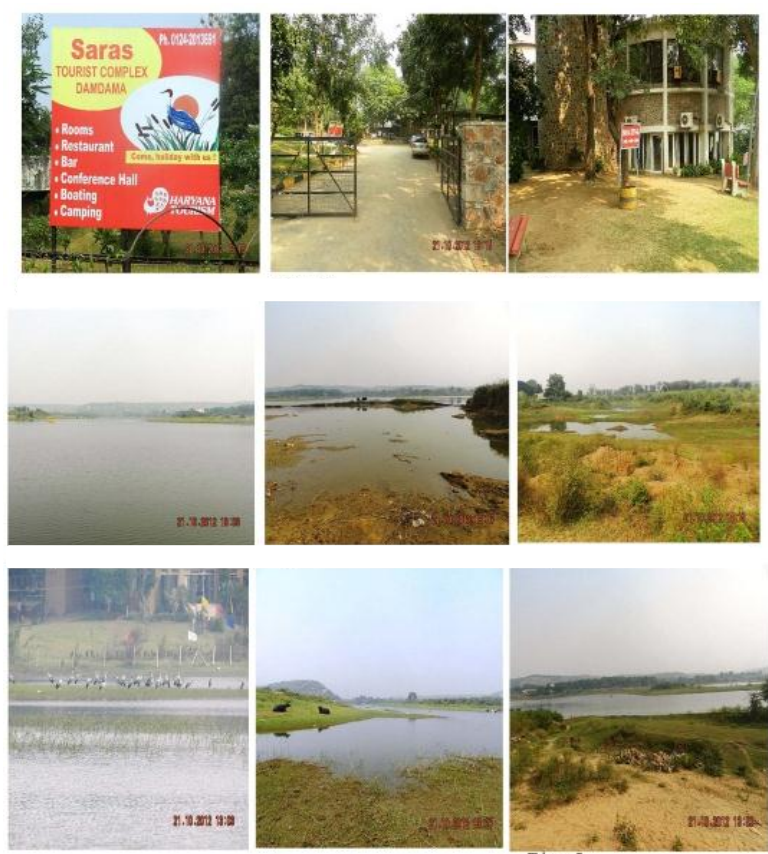

Fig.3. Showing the various views of Damdamma Lake in Gurgaon District in Haryana, India.

The overall position of Damdamma Lake is pitiable in all respect of care and habitat conservation. It is argued here that Damdamma lake need to be rehabilitated to impart it the status of winter home of winter migratory birds like Open-bill Stork and Eurasian Spoonbill which are not seen in these high numbers anywhere else in Haryana. Very extensive studies carved out by Gupta and Kaushik [1-2, 4-5, 8] in rural ponds between 2005-2012 indicate that in the first place these two birds are seldom seem, or even if observed, seem to be passage birds for 2-3 days in Umri village in September and March only. The fascinating birds observed on its campus include Yellow-Legged Green Pigeon Treron phoenioptera, Red Collared Dove Streptopelia tranquebarica, Rose-ringed Parakeet Psittacula krameri, Indian Roller Coracias benghalensis, Indian Grey Hornbill Ocyceros birostris, Brown-headed Barbet Megalaima zeylanica, Coppersmith Barbet 
Megalaima haemacephala, Wire-tailed Swallow Hirundo smitbii, Eurasian Golden Oriole Oriolus oriolus, Indian Pitta Pitta brachyuran, Common Crested Lark Galarida cristata, Brahminy Starling Sturnus pagodarum, Rufous Treepie, Red-vented Bulbul Pycnonotus cafer, Yellow-eyed Babbler Chrysomma sinense, Lesser Pied Kingfisher Ceryle rudis, Indian Robin Saxicoloides fulicata, Paddyfield Pipit Anthus rufulus, Yellow Wagtail Motacilla flava, White Wagtail Motacilla alba. It is recommended that the entire precincts of Damdamma Lake be regenerated by way of ensuring proper water sheets expanse, Kikar trees on the brim and multiple land platforms within the precincts of Damdamma Lake regimes of water expanse. Damdamma Lake can be promoted as the largest Wintering Home for large sized migratory birds of global significance.

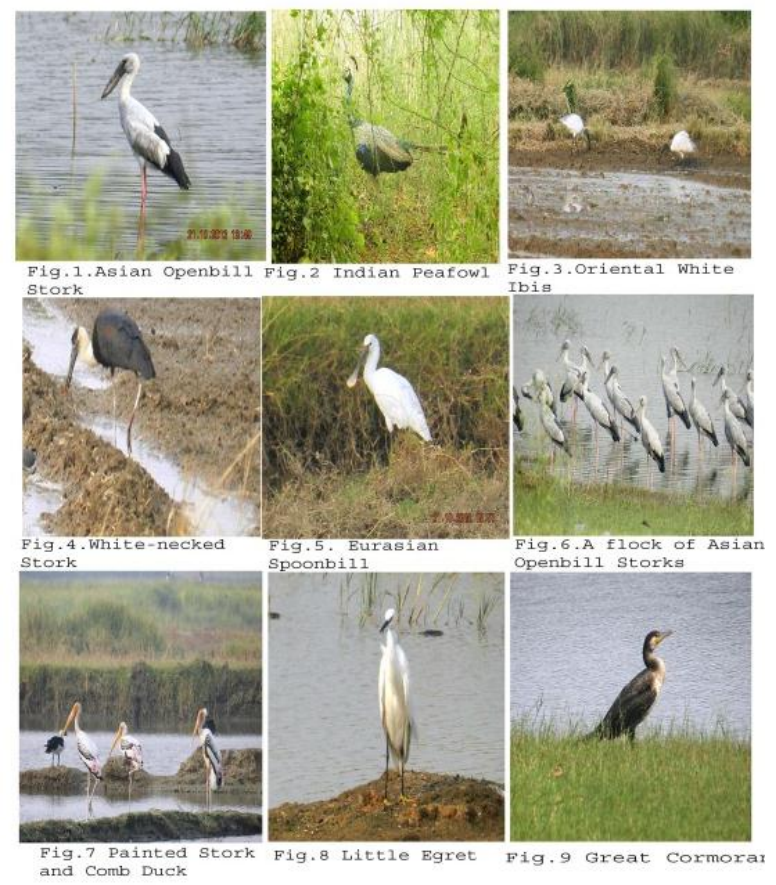

Fig.4. Prominent wetland birds observed at Damdamma Lake in Gurgaon District in Haryana, India during 2005-12.

\section{CONCLUSION}

The prominent winter migratory birds observed from Damdamma Jheel. Damdamma Lake can be promoted as the largest Wintering Home for large sized migratory birds of global significance.

\section{ACKNOWLEDGEMENTS}

The authors wish that the old glory of DAMDAMMA JHEEL will be restored by
District Authorities of Gurgaon in conjunction with Tourism Department, Haryana.

\section{REFERENCES}

1. Gupta RC \& Kaushik TK (2010a) Determination of the domain of spectrum concerning diversity of endangered winter visitor wetland birds in Haryana. J. Expt. Zool. India. 13(2):349-354.

2. Gupta RC \& Kaushik TK (2010b) Computation of wetland birds in rural areas of Kurukshetra, Haryana, India. J. Natcon. 22(1):1-11.

3. Gupta RC \& Kaushik TK (2010c) On the causative factors responsible for the pathetic plight of Yellow wattled Lapwing in Kurukshetra suburbs J.Natcon. 22(2):181-187.

4. Gupta RC \& Kaushik TK (2010d) Determination of spectrum of winter migratory birds in Yamunanagar district in Haryana (India). Environment conservation Journal. 11(3):37-43.

5. Gupta RC \& Kaushik TK (2010e) Understanding Rural Ponds' Migratory Avian Diversity in Panchkula District in Haryana, India. J. Adv. Zool. 31(2):117-123.

6. Gupta RC \& Kaushik TK (2011a) On the fast depleting trends of Cormorants in Kurukshetra wetlands in the last twenty five years. J. Expt. Zool. India. 14(1):81-85.

7. Gupta RC \& Kaushik TK (2011b) On the fundamentatals of natural history and present threats to Red-wattled Lapwing in Kurukshetra environs. J. Appl. \& Nat. Sci. 3(1):62-67.

8. Gupta RC \& Kaushik TK (2011c) Insight into Wetland Winter Migratory Avian Biodiversity in Hathnikund Barrage in Haryana State in India. International Journal of Life Sciences. 5(1):39-43.

9. Gupta RC, Kaushik TK \& Kumar S (2009) Analysis of winter migratory Wetland Birds in Karnal district in Haryana. J Adv Zool. 30(2):104-117.

10. Gupta RC, Kaushik TK \& Kumar S (2010a) Evaluation of the extent of wetland birds in district Kaithal, Haryana, India. J Appl \& Nat Sci. 2(1):77-84.

11. Gupta RC, Kaushik TK \& Kumar S (2010b) An account concerning arrival and departure time of few selected winter migratory birds in Haryana rural ponds. Environment conservation Journal. 11(1\&2):1-9.

12. Gupta RC, Parasher M \& Kaushik TK (2010) Analysis of Avifauna of Chilchilla Bird Sanctuary in Haryana, India. J Adv Zool. 31(1):35-44.

13. Gupta RC, Parasher M \& Kaushik TK (2011a) An Enquiry into the Avian Biodiversity of Bhindawas Bird Sanctuary in Jhajjar District in Haryana State in India. Journal of Experimental Zoology, India. 14(2): 457-465.

14. Gupta RC, Parasher M \& Kaushik TK (2011b) An Account on the Wetland Birds Diversity in Sultanpur National Park in Gurgaon District in 
Haryana State in India. Journal of Nature Conservation. 23(2):203-213.

15. Gupta RC, Kaushik TK \& Parasher M (2011c) On the death of an enchanting Bird Sanctuary and a robust wetland in Kaithal district in Haryana, India. International Journal of current life sciences. 1(3):48-54.

16. Gupta RC, Kaushik TK \& Parasher M (2012) Documentation of avian diversity of Khaparwas Bird Sanctuary in Jhajjar district in Haryana, India. International journal of life sciences. 6(1):10-20.

17. Ali S (1996) The Book of Indian Birds. 12th Edition (Revised \& enlarged): Oxford University Press. Mumbai.

18. Ali S \& Ripley S D (1987) Handbook of the birds of India and Pakistan together with those of Bangladesh, Nepal, Bhutan and Sri Lanka.1- 10 Vols. Oxford University Press. New Delhi.

19. Birdlife International (2001) Threatened Birds of Asia: The Birdlife International Red Data BookCambridge. UK. Birdlife International 246PP.

20. Grimmet R \& Inskipp T (1998) Inskipp C. Birds of the Indian subcontinent. Oxford University Press. Delhi.

21. Kumar A, Sati JP, Tak PC \& Alfred JRB (2005) Handbook on Indian Wetland Birds and their Conservation. Published by Director. Zool Surv. India. i-xxvi: 1-468.

22. Manakadan R \& Pittie A (2011) Standardised Common and Scientific Names of the Birds of Indian Subcontinent. Buceros. 6(1): i-ix, 1-38. 


\section{Supplementary Data}

Table.1. Checklist of avifauna of Damdamma Jheel in Gurgaon district in Haryana, India.

\begin{tabular}{|c|c|c|c|}
\hline 1 & Little Grebe & $\mathrm{R}$ & Tachybaptaus rufficollis (Pallas, 1764) \\
\hline 2 & Little Cormorant & $\mathrm{R}$ & Phalacrocorax niger (Vieillot, 1817) \\
\hline 3 & Great Cormorant & $\mathrm{R}$ & Phalacrocorax carbo (Linnaeus, 1758) \\
\hline 4 & Little Egret & $\mathrm{LM}$ & Egretta garzetta (Linnaeus, 1766) \\
\hline 5 & Grey Heron & WM & Ardea cinerea Linnaeus, 1758 \\
\hline 6 & Purple Heron & $\mathrm{LM}$ & Ardea purpurea Linnaeus, 1766 \\
\hline 7 & Large Egret & LM & Casmerodius albus (Linnaeus 1758) \\
\hline 8 & Median Egret & $\mathrm{LM}$ & Mesophoyx intermedia (Wagler, 1829) \\
\hline 9 & Cattle Egret & $\mathrm{R}$ & Bubulcus ibis (Linnaeus, 1758) \\
\hline 10 & Indian Pond-Heron & $\mathrm{R}$ & Ardeola grayii (Sykes, 1832) \\
\hline 11 & Painted stork & $\mathrm{LM}$ & Mycteria leucocephala (Pennant, 1769) \\
\hline 12 & White-necked Stork & $\mathrm{LM}$ & Ciconia episcopus (Boddaert, 1783) \\
\hline 13 & Asian Open-bill Stork & WM & Anastomus oscitans Boddaert, 1787 \\
\hline 14 & Oriental White Ibis & LM & Threskiornis melanocephalus (Latham,1790) \\
\hline 15 & Eurasian Spoonbill & WM & Platalea leucorodia Linnaeus, 1758 \\
\hline 16 & Comb Duck & WM & Sarkidiornis melanotos (Pennant, 1769) \\
\hline 17 & Gadwall & WM & Anas strepera Linnaeus, 1758 \\
\hline 18 & Spot-billed Duck & WM & Anas poecilorhyncha J.R. Forester, 1781 \\
\hline 19 & Northern Shoveller & WM & Anas clypeata Linnaeus, 1758 \\
\hline 20 & Northern Pintail & WM & Anas acuta Linnaeus, 1758 \\
\hline 21 & Common Teal & WM & Anas crecca Linnaeus, 1758 \\
\hline 22 & Common Pochard & WM & Aythya ferina (Linnaeus, 1758) \\
\hline 23 & Brahminy Kite & $\mathrm{R}$ & Haliastur indus (Boddaert,1783) \\
\hline 24 & Black-shouldered Kite & $\mathrm{R}$ & Elanus caeruleus (Desfontaines,1789) \\
\hline 25 & Black Kite & $\mathrm{R}$ & Milvus migrans (Boddaert,1783) \\
\hline 26 & Shikra & $\mathrm{R}$ & Accipiter badius (Temminck,1824) \\
\hline 27 & Lesser Spotted Eagle & $\mathrm{LM}$ & Aquila pomarina Brehm,1831 \\
\hline 28 & Common Quail & $\mathrm{R}$ & Coturnix coturnix (Linnaeus,1758) \\
\hline 29 & Jungle Bush Quail & $\mathrm{R}$ & Perdicula asiatica (Latham,1790) \\
\hline 30 & Indian Peafowl & $\mathrm{R}$ & Pavo cristatus Linnaeus, 1758 \\
\hline 31 & Saras Crane & $\mathrm{R}$ & Grus antigone (Linnaeus, 1758) \\
\hline 32 & White-breasted Waterhen & $\mathrm{R}$ & Amaurornis phoenicurus (Pennant, 1769) \\
\hline 33 & Purple Moorhen & $\mathrm{R}$ & Porphyrio porphyrio (Linnaeus, 1758) \\
\hline 34 & Common Moorhen & WM & Gallinula chloropus (Linnaeus, 1758) \\
\hline 35 & Common Coot & WM & Fulica atra Linnaeus, 1758 \\
\hline 36 & Pheasant-tailed Jacana & $\mathrm{LM}$ & Hydrophasianus chirurgus (Scopoli, 1786) \\
\hline 37 & Bronze-winged Jacana & $\mathrm{R}$ & Metopidius indicus (Latham, 1790) \\
\hline 38 & Kentish Plover & WM & Charadrius alexandrinus Linnaeus, 1758 \\
\hline 39 & Red-wattled Lapwing & $\mathrm{R}$ & Vanellus indicus (Boddaert, 1783) \\
\hline 40 & White-tailed Lapwing & WM & Vanellus leucurus (Lichtenstein, 1823) \\
\hline 41 & Spotted Redshank & WM & Tringa erythropus (Pallas, 1764) \\
\hline 42 & Common Redshank & WM & Tringa totanus (Linnaeus, 1758) \\
\hline 43 & Common Sandpiper & WM & Actitis hypoleucos Linnaeus, 1758 \\
\hline 44 & Common Greenshank & WM & Tringa nebularia (Gunner,1767) \\
\hline 45 & Marsh Sandpiper & WM & Tringa stagnatilis (Bechstein,1803) \\
\hline 46 & Wood Sandpiper & WM & Tringa glareola Linnaeus, 1758 \\
\hline 47 & Black-winged Stilt & $\mathrm{R}$ & Himantopus himantopus (Linnaeus, 1758) \\
\hline 48 & Pied Avocet & WM & Recurivirostra avosetta Linnaeus, 1758 \\
\hline 49 & River Tern & $\mathrm{R}$ & Sterna aurantia J.E.Gray, 1831 \\
\hline 50 & Yellow-Legged Green Pigeon & $\mathrm{R}$ & Treron phoenioptera (Latham,1790) \\
\hline 51 & Blue Rock Pigeon & $\mathrm{R}$ & Columba livia Gmelin,1789 \\
\hline 52 & Oriental Turtle Dove & $\mathrm{LM}$ & Streptopelia orientalis (Latham,1790) \\
\hline 53 & Eurasian Collared Dove & $\mathrm{R}$ & Streptopelia decaocto (Frivaldszky,1838) \\
\hline 54 & Red Collared Dove & $\mathrm{R}$ & Streptopelia tranquebarica (Hermann,1804) \\
\hline 55 & Spotted Dove & $\mathrm{R}$ & Streptopelia chinensis (Scopoli,1786) \\
\hline 56 & Little Brown Dove & $\mathrm{R}$ & Streptopelia senegalensis (Linnaeus,1766) \\
\hline 57 & Alexandrine Parakeet & $\mathrm{R}$ & Psittacula eupatria (Linnaeus,1758) \\
\hline 58 & Rose-ringed Parakeet & $\mathrm{R}$ & Psittacula krameri (Scopoli,1769) \\
\hline 59 & Pied crested Cuckoo & SM & Clamotor jacobinus (Boddaert,1783) \\
\hline 60 & Common Hawk Cuckoo & SM & Hierococcyx varius (Vahl,1797) \\
\hline 61 & Indian Cuckoo & SM & Cuculus micropterus Gould,1838 \\
\hline 62 & Asian Koel & $\mathrm{R}$ & Eudynamys scolopacea (Linnaeus,1758) \\
\hline 63 & Greater Coucal & $\mathrm{R}$ & Centropus sinensis (Stephens,1815) \\
\hline 64 & House Swift & $\mathrm{R}$ & Apus affinis (J.E.Gray,1830) \\
\hline 65 & Lesser Pied Kingfisher & $\mathrm{R}$ & Ceryle rudis (Linnaeus, 1758) \\
\hline 66 & White-breasted Kingfisher & $\mathrm{R}$ & Halcyon smyenensis (Linnaeus,1758) \\
\hline 67 & Blue-cheeked Bee-eater & WM & Merops persicus Pallas, 1773 \\
\hline 68 & Chestnut-headed Bee-eater & $\mathrm{R}$ & Merops Ieschenaultia Vieillot,1817 \\
\hline 69 & Green Bee-eater & $\mathrm{R}$ & Merops orientalis Latham,1801 \\
\hline 70 & Indian Roller & $\mathrm{R}$ & Coracias benghalensis (Linnaeus,1758) \\
\hline 71 & Common Hoopoe & $\mathrm{R}$ & Upupa epops Linnaeus, 1758 \\
\hline 72 & Indian Grey Hornbill & $\mathrm{R}$ & Ocyceros birostris (Scopoli,1786) \\
\hline
\end{tabular}




\begin{tabular}{|c|c|c|c|}
\hline 73 & Brown-headed Barbet & $\mathrm{R}$ & Megalaima zeylanica (Gmelin,1788) \\
\hline 74 & Coppersmith Barbet & $\mathrm{R}$ & Megalaima haemacephala (P.L.S.Muller,1776) \\
\hline 75 & Wire-tailed Swallow & $\mathrm{R}$ & Hirundo smithii Leach,1818 \\
\hline 76 & Common Swallow & $\mathrm{R}$ & Hirundo rustica Linnaeus, 1758 \\
\hline 77 & Eurasian Crag Martin & LM & Hirundo rupestris Scopoli,1769 \\
\hline 78 & Great Grey Shrike & $\mathrm{R}$ & Lanius excubitor Linnaeus, 1758 \\
\hline 79 & Bay-backed Shrike & $\mathrm{R}$ & Lanius vittatus (Valenciennes,1826) \\
\hline 80 & Rufous backed Shrike & $\mathrm{R}$ & Lanius schach Linnaeus, 1758 \\
\hline 81 & Brown Shrike & WM & Lanius cristatus Linnaeus, 1758 \\
\hline 82 & Eurasian Golden Oriole & SM & Oriolus oriolus (Linnaeus,1758) \\
\hline 83 & Black Drongo & $\mathrm{R}$ & Dicrurus macrocercus Vieillot,1817 \\
\hline 84 & Indian Pitta & $\mathrm{R}$ & Pitta brachyura (Linnaeus,1766) \\
\hline 85 & Red-winged Bush Lark & $\mathrm{R}$ & Mirafra erythroptera Blyth,1845 \\
\hline 86 & Ashy-crowned Sparrow Lark & $\mathrm{R}$ & Eremopterix grisea (Scopoli,1786) \\
\hline 87 & Common Crested Lark & $\mathrm{R}$ & Galarida cristata (Linnaeus,1758) \\
\hline 88 & Eastern Skylark & $\mathrm{R}$ & Alauda gulgula Franklin,1831 \\
\hline 89 & Brahminy Starling & $\mathrm{R}$ & Sturnus pagodarum (Gmelin,1789) \\
\hline 90 & Rosy Starling & WM & Sturnus roseus (Linnaeus,1758) \\
\hline 91 & Common Starling & WM & Sturnus vulgaris Linnaeus, 1758 \\
\hline 92 & Asian Pied Starling & $\mathrm{R}$ & Sturnus contra Linnaeus, 1758 \\
\hline 93 & Common Myna & $\mathrm{R}$ & Acriditheres tristis (Linnaeus,1766) \\
\hline 94 & Bank Myna & $\mathrm{R}$ & Acridotheres ginginianus (Latham,1790) \\
\hline 95 & Rufous Treepie & $\mathrm{R}$ & Dendrocitta vagabunda (Latham,1790) \\
\hline 96 & House Crow & $\mathrm{R}$ & Corvus splendens Vieillot,1817 \\
\hline 97 & Jungle Crow & $\mathrm{R}$ & Corvus macrorhynchos Wagler,1827 \\
\hline 98 & Small Minivet & $\mathrm{R}$ & Pericrocotus cinnamomeus (Linnaeus,1766) \\
\hline 99 & Red-vented Bulbul & $\mathrm{R}$ & Pycnonotus cafer (Linnaeus,1766) \\
\hline 100 & Yellow-eyed Babbler & $\mathrm{R}$ & Chrysomma sinense (Gmelin,1789) \\
\hline 101 & Common Babbler & $\mathrm{R}$ & Turdoides caudatus (Dumont,1823) \\
\hline 102 & Striated Babbler & $\mathrm{R}$ & Turdoides earlie (Blyth,1844) \\
\hline 103 & Large Grey Babbler & $\mathrm{R}$ & Turdoidesmalcolmi (Sykes,1832) \\
\hline 104 & Jungle Babbler & $\mathrm{R}$ & Turdoides striatus (Dumont,1823) \\
\hline 105 & Ashy Prinia & $\mathrm{R}$ & Prinia socialis Sykes, 1832 \\
\hline 106 & Jungle Prinia & $\mathrm{R}$ & Prinia sylvatica Jerdon, 1840 \\
\hline 107 & Common Tailor Bird & $\mathrm{R}$ & Orthotomous sutorius (Pennant,1769) \\
\hline 108 & Oriental Magpie Robin & $\mathrm{R}$ & Copsychus saularis (Linnaeus,1758) \\
\hline 109 & Pied Bush Chat & WM & Saxicola caprata (Linnaeus,1766) \\
\hline 110 & Indian Robin & $\mathrm{R}$ & Saxicoloides fulicata (Linnaeus,1776) \\
\hline 111 & Blue Rock Thrush & $\mathrm{R}$ & Monticola solitarius (Linnaeus,1758) \\
\hline 112 & Great Tit & $\mathrm{R}$ & Parus major (Linnaeus,1758) \\
\hline 113 & Indian Tree Pipit & $\mathrm{R}$ & Anthus trivialis (Linnaeus,1758) \\
\hline 114 & Paddy-field Pipit & $\mathrm{R}$ & Anthus rufulus Vieillot,1818 \\
\hline 115 & Brown Rock Pipit & WM & Anthus similes Jerdon, 1840 \\
\hline 116 & Forest Wagtail & WM & Dendronanithus indicus (Gmelin,1789) \\
\hline 117 & White Wagtail & WM & Motacilla alba Linnaeus, 1758 \\
\hline 118 & Large Pied Wagtail & WM & Motacilla maderaspatensis Gmelin, 1789 \\
\hline 119 & Citrine Wagtail & WM & Motacilla citreola Pallas, 1776 \\
\hline 120 & Yellow Wagtail & WM & Motacilla flava Linnaeus, 1758 \\
\hline 121 & Grey Wagtail & WM & Motacilla cinerea Tunstall,1771 \\
\hline 122 & Purple Sunbird & $\mathrm{R}$ & Nectarinia asiatica (Latham,1790) \\
\hline 123 & House Sparrow & WM & Passer domesticus (Linnaeus, 1758) \\
\hline 124 & Baya Weaver & $\mathrm{R}$ & Ploeus philippinus (Linnaeus,1766) \\
\hline 125 & Black-breasted Weaver & $\mathrm{R}$ & Ploeus benghalensis (Linnaeus,1758) \\
\hline 126 & Red Avadavat & $\mathrm{R}$ & Amandava amandava (Linnaeus,1758) \\
\hline 127 & Spotted Munia & $\mathrm{R}$ & Lonchura punctulata (Linnaeus,1758) \\
\hline 128 & Common Rosefinch & WM & Carpodacus erythrinus (Pallas,1770) \\
\hline
\end{tabular}

Abbreviation: WM=Winter Migratory; $\mathrm{SM}=$ Summer Migratory; LM=Local Migratory; $\mathrm{R}=$ Resident; Res. Status $=$ Residential Status 